\title{
BILLGELİĞİ TACINI TAKAN ALP SALUR KAZAN
}

\author{
ALP SALUR KAZAN WEARING THE CROWN OF WISDOM
}

\section{Aynur KOÇAK*- Işılay KARA TEKGÜL ${ }^{* *}$}

\begin{abstract}
ÖZ: Dede Korkut Kitabı'nın katman katman işlenmiş ve okundukça hayran bırakan hikâyelerinden, insanlık sahasını aydınlatan kadim anlamlar ıșıldar. Salur Kazan'ın aktif biçimde rol aldığı hikâyeler de ışıldayan bu kaynağın güzide bir parçasıdır. Hikâyelerde birbirinden güzel birçok sıfatla anılan Salur Kazan, İç-Oğuz beylerinden biridir ve İç-Oğuz'un da Dış-Oğuz'un da beylerbeyidir. Onun aracılığı ile fiziksel ve ruhsal olarak alp tipinin tüm özellikleri can bulur. Salur Kazan'ın bir ejderhayı öldürmesi ile ilgili farklı yazılı kaynaklarda bilgiler yer alırken nihayet Türkistan/Türkmen Nüshası'yla hikâyenin tam metnine ulaşılabilmiştir. 13. Boy olarak anılan "Salur Kazan'ın Yedi Başlı Ejderhayı Öldürmesi” adlı hikâye, Salur Kazan'ın bir ejderhayla mücadelesini konu almaktadır. Kahraman merkezli anlatılarda, kahramanın mücadele ettiği varlık ve mücadele süreci, çeşitli semboller ile aktarılır. Tüm sembollerin taşıdığı ortak değer, kahramanın yolculuğunu, bireyleşmesini tamamlayarak bitirmesini vurgular. Bireyleşme kavramı, analitik psikolojide belirli arketipsel evreler ile şekillenir. Evrelerin başarıyla tamamlanması kahramanın psişe bütünlüğü açısından hayati önem taşır. Salur Kazan'ın Yedi Başlı Ejderhayı Öldürmesi, analitik psikolojinin unsurları ile çözümlenirse ejderha ile mücadele simgesi, kahramanın kendi psişesinin karanlık yönlerine karşı savaşını temsil eder. Kazan'ın yaşadığı bu mücadelede başından geçen olaylar, bilinç seviyesinden bilinçdışına doğru yönelmiş bir kahramanın yolculuğudur. Gerçek bir alp olan Salur Kazan; psişesinin kuytularını keşfetmeye, aydınlanmaya ve bilge bir lider olmaya kendisi talip olur. Hikâyenin sonunda Kazan, ejderhayı yener böylece benliğini tanıyıp bireyleşme evrelerini başarıyla tamamlayarak zafere ulaşmış olur. Zorlu mücadelenin sonunda kazanılan büyük hazine, bilgeliğin gereği olan "kendini bilme" yani kadim bir taçtır. Bu anlatıyla birlikte Salur Kazan'ı “ bilge alp” tipi olarak anmak mümkün olacaktır.
\end{abstract}

Anahtar Kelimeler: Dede Korkut Hikâyeleri, Salur Kazan, arketip, korkunç anne, bireyleşme. ABSTRACT: From the stories of the Book of Dede Korkut, which are processed layer by layer and fascinated by reading, ancient meanings that light on the field of humanity shine. The stories in which Salur Kazan plays an active role are also a unique part of this glowing cause. Salur Kazan mentioned in the stories with many admirable attributes is one of the Inner Oghuz lords and the governor of the Inner-Oghuz and Outer-Oghuz. Through him, all the features of the alp type come to life physically and spiritually. While there is information in different written sources about Salur Kazan killing a dragon, the full text of the story finally reached with the Turkistan / Turkmen Copy. The story titled "Salur Kazan Killing the Seven-Headed Dragon", referred to as the 13th Clan, is about the fight of Salur Kazan with a dragon. In hero-centred narratives, the

${ }^{*}$ Prof. Dr. - Yıldız Teknik Üniversitesi Fen-Edebiyat Fakültesi Türk Dili ve Edebiyatı Bölümü / İstanbul - aynurnazkocak@hotmail.com (ORCID ID: 0000-0002-9555-1088)

** Yıldız Teknik Üniversitesi Sosyal Bilimler Enstitüsü Türk Dili ve Edebiyatı Anabilim Dalı Lisansüstü Öğrencisi / İstanbul - isilaykaratekgul@gmail.com (ORCID ID: 0000-00025533-9664)

This article was checked by Turnitin. 
creature and struggle process that hero fights are conveyed with various symbols. The common meaning of all symbols emphasizes the completion of the hero's journey by performing his individualization. The concept of individuation is shaped by certain archetypal phases in analytical psychology. Successful completion of the phases is vital for the hero's self-perception. If Salur Kazan's Killing of the Seven-Headed Dragon is resolved by elements of analytical psychology, the dragon-fighting symbol represents the hero's battle against the dark aspects of his psyche. The events that took place in this struggle of Kazan are the journey of a hero from the level of consciousness towards the unconscious. Salur Kazan, a real alp; He aspires to discover the nooks of his psyche, to become enlightened and to become a wise leader. At the end of the story, Kazan defeats the dragon, thereby achieving victory by recognizing his self and completing the stages of individuation. The great treasure earned at the end of the difficult struggle is "knowing yourself", an ancient crown that is the necessity of wisdom. With this narrative, it will be possible to mention Salur Kazan as the "wise alp" type.

Keywords: Dede Korkut stories, Salur Kazan, archetype, scary mother, individuation.

"Alplar beyler gören var mı Kazan gibi"

Şecere-i Terâkime

\section{Giriş}

Oğuz dünyasını anlatan Dede Korkut Kitabı'ndaki anlatıların merkezinde Oğuz alpları yer alır. Ali Duymaz’a göre, bu kitap, adlarına Oğuznâme düzülen alpların kitabıdır (1999: 121). Bu alpların maceraları vasıtasıyla Oğuz insanına, değerlerine, zafiyetlerine, yaşayışına ve onların doğumlarına, yetişmelerine, maceralarına, aşklarına tanık oluruz. Onların var oluş maceraları hiç bitmez ${ }^{1}$. Anlatılarda çok yönlü özellikleriyle ve mücadeleleriyle alplar, kahraman modelinin en güzel örneklerini sunarak kahramanlık sembolü olur. Bu alpların başında da Salur Kazan gelir². İç-Oğuz beylerinden olan Salur Kazan, hem İç-Oğuz'un hem de Dış-Oğuz'un beylerbeyidir. Onun vasıtasıyla hem fiziki ve hem de ruhi olarak "destanî alp tipi"nin tüm özelliklerini tanımak mümkün olur³. Hanlar Hanı Bayındır Han'ın güveyisi olan Salur Kazan, hikâyelerde ismi en çok geçen alplardan biridir ve o, kahramanlığını tekrar tekrar gösterir ve genç Oğuz nesli için bir örnek seviyesine yükselir (Abdulla, 2012: 31).

Anlatıların merkez kahramanı Salur Kazan, birkaç hikâye dışında hikâyelerin tamamında karşımıza çıkar. Hikâyelerde Kazan'ın ayrıntılı tavsifinin yapıldığı ve övüldüğü görülür. Anlatılar boyunca pek çok yönü sergilenen öncü bir lider ve toplumun ümidi (Abdulla, 2012: 280) Salur

\footnotetext{
${ }^{1}$ Korkmaz, Oğuz alplarından Basat'ı değerlendirirken “Türk edebiyatında pek sözü edilmeyen bir alp-bilge tipi örneği oluşturduğunu ifade eder. Araştırmacıya göre, "Bu tip, eski ulu kişilerin, şamanların veya kamların bilgeliğini Alp tipinin gücüyle birleștiren ve daha sonra İslami kabullerin etkisiyle bilgeliği "eren"liğe dönüştüren derin ve asli karakterli bir geçiş tipidir. Ve (...) ihmal edilen bu Alp-bilge tipinin bilimsel anlamda açımlanmaya ve tartışılmaya ihtiyacı" (1999: 267) olduğu kanaatindedir.

2 Duymaz'a göre, "IX-X. yüzyıllardaki Oğuz-Kıpçak mücadelesi ile XIV-XV. yüzyıllardaki Akkoyunlu mücadelesi gibi iki tarihi ve Türkistan ile Anadolu gibi iki coğrafî tabakaya sahip olan Dede Korkut hikâyelerinin gösterdiğine göre Salur Kazan, düşmanlarının destanlarında da yer bulabilecek kadar güçlü bir Oğuz alpı tipidir" (1997: 72).

3 Alp tipinin özellikleri ve Salur Kazan üzerine yapılan müstakil çalışmalar için bk. (Kaplan, 1976; Duymaz, 1996, 1997; Bars, 2010).
} 
Kazan; bir insandır, bir oğuldur, bir babadır, bir eştir, bir beydir, bir kahramandır. Hünerli ve erdemli Oğuz alplarından biri olan Kazan aynı zamanda danışılan bilge bir şahsiyettir (Duymaz, 1997: 18).

Salur Kazan'ın destanî kimliğine dair çeşitli tarihi kaynaklarda da çeşitli bilgiler yer almaktadır ${ }^{4}$. Bu kaynaklarda Kazan, alpların başı veya namlı alplardan biri (Duymaz, 1997:24-25) olarak anılmaktadır. Düşmanlarının destanlarında bile yer bulabilecek kadar güçlü bir Oğuz kahramanı olan Salur Kazan, "Kobılandı Batır Destanı"nda gözlerinden zehir saçan, alnında kar, kirpiğinde buz donduran, ala öküz gibi bağıran, öfkeli Kazan Han (Duymaz, 1997: 31) olarak tasvir edilir.

Duymaz, Salur Kazan'la ilgili incelemesinde “Salur Kazan'ın ejder öldürmesi” motifine dikkat çekerek "Salur Kazan'ın mütekâmil bir destanın kaybolmuş epizotlarından biri olarak değerlendirilebileceğini dile getirerek "ejder öldürme"nin de Ŏ̆uz Kağan ve diğer destanlarda olduğu gibi ergenliğe geçişin, alplı̆̆ın ve nam salmanın tescili olarak yorumlanması gerektiğini (1997: 64) belirtir. Dede Korkut Kitabı'ndaki “Salur Kazan'ın Tutsak olup Uruz'un Çıkarttığı Boy"da Kazan, bir soylamasında böyle bir anlatıya göndermede bulunulur:

"Yedi başlı ejderhaya yetüp vardum

Heybetinden sol gözüm yaşardı

Hey gözüm namet gözüm muhannes gözüm

Bir yılandan ne var ki korhdun, dedüm" (Ergin, 2018: 237)

Gökyay, bir yazılı kaynağa dayanarak Salur Kazan'ın ejder öldürmesiyle ilgili başka destanların bulunabileceğini ifade eder (Gökyay, 2000: CLXXIII-CLXXIV). “Şecere-i Terakime”de de yer alan ve Salur Kazan'ın övüldügü manzumede gökten inen bir yılanın insanları yuttuğunu ve bu yılanın başını Salur Kazan'ın kestiğinden söz eden dizeler yer almaktadır:

“Gökyüzünden büyük bir yılan inip geldi

Gördüğü her insanı yutardı

Salur Kazan aman vermeden başını kesti

Kahramanlar ve beyler Kazan gibisini göreniniz var mı?" (Kargı Ölmez,1996: 265).

Farklı kaynaklarda ve Dede Korkut hikâyelerinde yer verilen Salur Kazan'ın ejderha öldürme konusunun yer aldığı tam metne "Türkistan/Türkmen Nüshası" olarak adlandırılan yeni el yazmasıyla ulaşılabilmiştir5. "Salur Kazan'ın Yedi Başlı Ejderhayı Öldürmesi” adlı metin, Salur Kazan'ı yeni bir bakış açısıyla değerlendirme imkânı veren bir

\footnotetext{
4 Bu kaynaklar Dede Korkut Kitabı'nın dışında Şecere-i Terâkime”, "Câmiü’t-Tevârih, "Selçuknâme", "Hazihi er-risâleti min kelimâti Oğuznâme el-meșhur bi-atalar sözü", "Tuhfetü'ssürûr" gibi eserlerde Salur Kazan ismi geçmektedir (Duymaz, 1997: 20-26). Hem Oğuz hem de Kıpçak sahası Türk destanlarında adı çok geçen Oğuz alpıdır (Duymaz, 1996: 49).

${ }^{5}$ Söz konusu el yazması için bk. (Azmun, 2019; Ekici, 2019).
} 
hikâyedir. Kemal Abdulla'nın ifade ettiği gibi "Dede Korkut dünyası bugün de bizi şaşırtmaktan usanmıyor, yorulmuyor. Bize, bugün de kendimizi daha yakından tanımamız için yeni yeni anahtarlar veriyor. Sadece bu anahtarlara uygun kilitleri bulmak gerekiyor" (Abdulla, 2012: 36). Bu inceleme Salur Kazan'a ait mühim bir kapıyı, uygun bir kilitle açma amacı gütmektedir. Böylece bu kapının kilidini açmak mümkün olacaktır.

“Salur Kazan'ın Yedi Başlı Ejderhayı Öldürmesi” hikâyesinin iki bölümden oluştuğunu söylemek mümkündür. Birinci bölüm veya giriş olarak değerlendirebileceğimiz kısımda Salur Kazan'ın kendi ağzından düșmana karșı kazandığı bir zafer anlatılır. Salur Kazan'ın kendisini anlattığı ilk bölümden sonra anlatıcı değişir ve Salur Kazan'ın başından geçen yeni bir olay, hâkim bakış açısı ile anlatılır. Hikâyede Salur Kazan, askerleriyle avdayken bir süre sonra ava yalnız devam etmek ister ve tek başına kaldıktan sonra karşısına yedi yer evreni bir ejderha çıkar. Ejderha ile mücadele etme konusunda önce kararsız kalsa da Lala Kılbaş'ın teşvikiyle ejderhayla savaşmaya karar verir.

Salur Kazan'ın ejderhayla mücadelesini anlatan hikâye, olay örgüsü ve simgesel boyutu ile Jung'un "evrensel kahraman miti" olarak değerlendirilebilecek bir anlatı örneğidir. Bu örneklerde kahraman daima ejderha, yılan, canavar, şeytan vb. formdaki kötülüğü yenen, halkını yıkım ve ölümden kurtaran güçlü bir insan ve tanrı insan (Jung, 2017: 74) olarak görülür. Özellikle mitik anlatılarda karşımıza çıkan ejderhayla mücadele, görünürde doğayla mücadeleyi anlatsa da alt katmanlarda sembolik olarak insanın iç mücadelesini yani "kendini bilme" konusunu yansıtır. İncelememizde "Acaba Salur Kazan bilinçdışının karanlıklarına yol alabilecek ve kendiyle yüzleşebilecek midir? Benliğinin ${ }^{6}$ (özbeninin) gelişmesiyle derin bir algılamayla yaşamı daha derinden kavrayabilecek midir? Salur Kazan hem bilinci7 hem de bilinçdışını kucaklayan bu çemberin içinde, dönüşüm ve değişimden geçip dengeye ulaşarak 'bilge alp' olarak toplumla bütünleşebilecek midir?" gibi sorulara cevaplar aranacak;

\footnotetext{
6 Özben (benlik/self/kendilik), arketipini Jung: "Ampirik açıdan kendilik rüyalarda, mitlerde ve masallarda kral, kahraman, peygamber, kurtarıcı vb. "Üst düzey kişilik" figürü veya daire, kare, quadratura circuli (dairenin kareye dönüștürülmesi), çarmı vb. gibi bütünlük simgesi halinde ortaya çlkar. (...) Karşıtların birliğini temsil ettiğinde örneğin yang'la ying'in, düşman kardeşlerin, kahramanla düşmanının (baş düşman, ejderha) Faust'la Mephistopheles'in vb. etkileşimi tarzında birleşmiş ikilik olarak da ortaya çıkabilir." (2016a: 48) şeklinde açıklar.

7 Bilinç (consciousness), bireyin çevresine uyum sağlamasına yardım eden gerçeklikle bağlantı kurmanın bir yoludur. Bilincin merkezinde, genellikle bireyin kendini tanımlayışına karşılık gelen ego bulunmaktadır. Bilinç ve bilinçdışı kavramlarını Jung: “Bilinçten psişik içeriklerin ben'le ilişkisini anlıyorum. Ben'in bu ilişkiyi bizatihi algıladığı ölçüde. Ben'in bizatihi algılamadığı ilişkileri bilinçdıșıdır. Bilinç, psişeyle aynı şey değildir çünkü psişe bütün psişik içeriklerin toplamını temsil eder." (Jung, 2016a: 14) diyerek izah eder. Jung'a göre bilinçdışının, biri kişisel bastırmalarının toplandığı kişisel bilinçdışı; diğeri de tüminsanların psişelerinde var olan arketipik ögelere ait kalıntıların toplandığı kolektif bilinçdışı olmak üzere iki yönü vardır.
} 
anlatıdaki olaylar ve semboller analitik psikolojinin temel yaklaşımları ile çözümlenecektir.

Kahraman arketipinin gerisinde, insanın kendisiyle yüzleşmesi ve kendi psişesini tanıma yolculuğu mevcuttur. İnsan, ömrü boyunca bir değişim, dönüşüm içindedir. Jung psikolojisinde rüyalar aracılığı ile bu değişim dönüşüm evrelerinin psişedeki süreçleri izlenir. Psişe alanın merkezinde bulunan ve aynı zamanda tüm psişeyi kapsayan öz, bir çekirdeğe benzetilir. Tüm imgelerin, rüyaların sembollerin kaynağı bir tür "nükleer atom" olan bu çekirdek kabul edilir. Çekirdekten yani özden gelen direktifler, farklı bireylerde incelendiğinde sanki bir çeşit düzenleyicinin ya da yönlendiricinin bireyleşme sürecini aynı adımlarla şekillendirdiği gözlemlenmiştir. Bu adımlara geçmeden önce bireyin bilinç seviyesinde belli bir olgunluğa gelmiş olması gerekir. Ego aktif olmadan psişe kendindeki süreçleri idrak edemeyeceğinden, bilincin önemi açıtır. Daha sonra bilinçdışı ile ilk temas kurulur ve dört aşama şekillenir.

Jung psikolojisinde bireyleşme kavramı, birbiri ardına şekillenen dört arketipik evreyle gerçekleșebilir. Psişenin ${ }^{8}$ karanlık yönü "gölge"9 arketipinin bilinç alanına yükseltilmesi, birinci evreyi oluşturur. Gölgenin fark edilmesi rüyalarda genellikle aynı cinsten bir kişi ile gerçekleşir. Çoğunlukla bireysel bilinçdışı alanında beliren gölge ile psişe arasındaki mesele halledilirse ikinci arketipik evrede, anima" 10 ve "animus" gelecektir. $\mathrm{Bu}$ yeni aşamada, değişik ve farklı sorunlar ortaya çıkar. Psişede kaynağı gölgeye göre daha derinlere ait olan anima ve animus ile yüzleșen benlik, bütünlüğe doğru ilerlemeye başlar. Üçüncü evrenin merkezi çoğunlukla kolektif bilinçdışıdır ve psişe kendi derinlerine vakıf olmaya başlar; "yaşlı

\footnotetext{
8 Jung, ruh ile psişe kavramlarının denkliğini aynı başlıkta eşleyerek fakat sonrasında ayrımlarından da bahsederek belirtmiştir. "Bilinçdıșının yapısıyla ilgili araștırmalarımda ruhla psișe arasında kavramsal bir ayrım yapmak zorunda kaldım. Psişeden bilinçdışı kadar bilinçli de olan bütün psişik süreçlerin tamamını anlıyorum. Öte yandan ruhtan en iyi şekilde kişilik diye tanımlanabilen, sınırları açıkça çizilmiş işlev kompleksini anlıyorum" (Jung, 2016a: 54). Psişik olanın hiçbir şey olmadığı ya da gazdan bile uçucu olduğuna dair yaygın kanıyı paylaşmıyorum. Tam tersine psikenin insan yaşamının en güçlü olgusu olduğu görüşündeyim (Jung, 2016b: 46). Görüldüğü üzere psişe, insan doğasında bilinç ve bilinçdışı alanın tamamını ifade eden toplam yapıya verilen addır.

9 Gölge, psişenin daha çok bireysel bilinçdışında şekillenir ve kişilerin istenmeyen kötü özelliklerini belirtmek için kullanılır, ego kişilik ile çatışmalar yaşayan karanlık vasıflarla donanmıș ve psişede ikinci bir kişilikmiş gibi varlık gösteren arketiptir.

10 Anima ve animus noktasında kişilerin karşıt cinsle olan ilişkileri de arketipik bir temele dayanır. Jung, kadınlardaki bu kontraseksüel arketipe animus; erkelerdekine de anima adını verir. Erkeğin içindeki dişi yön ve kadının içindeki eril yön, her iki cinsin bilinçdışında bir anlamda karşıtların birleşimini oluşturur (Steven, 2014: 100).
} 
bilge adam"11 ve "büyük ana"12 arketipleri bu evrede gerçekleşir. Gölge, anima- animus ve yaşlı bilge sırlamasında psişe, istenilen biçimde hareket ederse bütünlük ve birlik temsili gerçekleşeceğinden son evre "kendilik (benlik)" arketipi" olacaktır (Jacobi 2002: 149-187). Tüm aşamaların sonunda bireyleşmeyi başarmış bir kahraman şekillenmiş olur.

Jung'a göre, ego ${ }^{13}$, "yaşamın ilk yarısında kendini bilinçdışından sıyırıp toplumda bir yer edinerek kahramanca bir tutum sergiler. Bir kahraman sağlam bir işe ve eșe sahip olmayı başarır. Yaşamın ikinci yarısında da toplumdan kendini kopararak tekrar bilinçdışına geri dönen, fakat bunu yaparken kontrolü kaybetmeyen ego, yine bir kahramandır" (Segal, 2012: 149). Ele alınacak bu anlatının kurgusu, yaşamın ilk yarısı ve ikinci yarısı olarak değerlendirmeye uygun bir yapı arz etmektedir. Jung'un bireyin izlemesi gerekli olan yollar ekseninde ele alındığında kahramanın öncelikle bilinç düzeyi üzerinde durulup ardından bilinçdışındaki serüveni ve topluma katılımı yorumlanacaktır.

\section{Kahramanın Hükümdarı: Bilinç}

Kahraman merkezli bu anlatıda kahramanın doğumuna, yetişmesine, ad almasına iliş̧in bilgilere yer verilmemiştir. Kahramanın varoluş yolculuğunu değerlendirebilmek için ön bilgilere ihtiyaç vardır. Anlatı, Salur Kazan'ın bir alp olarak tanıtılmasıyla başlar. Bir mukaddime özelliği taşıyan bu bölümde Salur Kazan'ın düşmanla savaşı kendi dilinden aktarılır. Burada Kazan'ın zekâsı, gücü, kendine güveni, inancı gözler önüne serilir. Böylece fiziken ve ruhen güçlü bir kahraman portresi çizilir. Analitik psikolojiye göre mit, masal yahut destan gibi olağanüstülük taşıyan anlatılarda kahramanlar ve onların başından geçen olaylar, insan psişesini anlamak açısından son derece önemlidir. Halk anlatılarındaki sembollerle ilgili yorumlarda bulunan Estes'e göre bütün simgeler tek bir kişinin psişesinin özelliklerini tasvir eder; ama dış dünyadaki koşul ve ilişkileri de barındırdıkları için bu öyküleri nesnel olarak da algılanabilir (2016: 17). Bu sebeple Kazan'ın tanıtıldığı

\footnotetext{
11 Yaşlı bilge adamın ortaya çıkışını Jung: “Ruh türünün masallarda yaşlı bilge adam biçiminde görülme sıklığı rüyadakiyle aynıdır. Kahraman ne zaman kendisini, içinden ancak derin bir düşünce ya da şanslı bir fikrin- diğer bir deyișle ruhsal bir işlev yahut bir tür endopsișik özdevinimin- kurtarabileceği umutsuz ve çaresiz bir duruma düşse yaşlı adam hâsıl olur." (2016d:165) diyerek anlatır. Yaşlı bilge, daha çok psişenin kolektif bilinçdışında şekillenen arketiptir ve kahramanın mücadelesini zaferle sonuçlandırması için gerekli yönlendirmeleri yapar.

12 Büyük ana/ulu ana, simgesel arketiptir. Ulu ana, hayat, ölüm ve dönüşümün sırrıdır. İyi ana, toprak ananın olumlu yönü) Hayat prensibi ile birleşmişlik, doğum, sıcaklık, besin, koruma, verim, büyüme (yetişme, yeşerme), bereketi temsil eder. Korkunç ana ise toprak ananın olumsuz yüzünü içerir. Büyücü, cadı, baştan çıkarıcı, fahişe, femme fatale, korku, tehlike, karanlık, dışlanma, ölüm, korkutucu yüzündeki bilinçsizlikle sembolize edilir.

${ }^{13}$ Ego, (ben, Ich), kavramını Jung: “Benden, bilinç alanımın merkezini oluşturan, büyük ölçüde sürekliliği ve kimliği bulunan fikirler kompleksini anlıyorum. Bu nedenle benkompleksinden söz ediyorum. Ben-kompleksi bir bilinç durumu olduğu kadar bilincin içeriğidir de zira bir psişik öge ben-kompleksimle ilişkili olduğu ölçüde benim için bilinçlidir." (2016a: 13) şeklinde izah etmiştir
} 
bütün özellikler ve başından geçen olaylar da sembolik olarak Salur Kazan'ın psişesini temsil etmektedir.

Hikâyede bir ulak, Salur Kazan'a kendisi ile savaşmaya gelenleri haber verir. Düşman sayısı az iken Salur Kazan rahat davranır. Ancak sayı doksan bin olunca zırhını giyinir, yüz bin olunca da Allah'tan yardım diler. Düşmanın gücü sayllarla dile getirilir. Kazan, düşmanla savașta stratejik yönlere, o bölgeleri en iyi savunacak yiğitleri gönderir. Yedinci ${ }^{14}$ günün sonunda zafer kazanır. Zaferden sonra savaşta yanında olan yiğitlerin mertebesini yükseltir, bazılarına da beylik verir. Anlatılarda kahramanın yanındaki yardımcı kişiler, kahramanın yolcuğunu anlamada mühim ipuçlarını barındırır. Kahramanı harekete geçiren güç yani "ulak", kahramanın psişesinin bilinç seviyesini tetikler. Kahramanın psişesi, savaş esnasında son derece bilinçli süreçler içerisindedir. Düşmanı bozguna uğratacak yiğit askerlerini bilir ve onları en stratejik noktalara yerleştirir. Kendisi de "merkezde" durur. Sağdan ve soldan gelecek tüm tehlikelerin "farkında"dır ve tecrübeleri ile savaşı yedi günde kazanır.

Hikâyenin başlangıç bölümünde, bilinçdışı süreçlerde henüz deneyimsiz kahramanın, bilinç alanında ne kadar yetkinleştiği gözler önüne serilir. Salur Kazan, âdemler evreni, İslâm dini kuvveti, Konur atlı, Salur iği, Eymür'ün sevinci, Dulkadir delisi, Savalan Dağı yaylaklı, Sarıkamış kışlaklı, seksen bin er heybetli, kara çeliğin keskini, sürcidanın (mızrağın) çeviği, sahar okların temreni, Azerbaycan lengeri, Padişahın vekili (Ekici, 2019:201) olarak anılır. Ulaş Oğlu Salur Kazan; evrendir, kuvvettir, vekildir, heybetlidir.

Kahraman, bilinçdışı süreçlerde ustalaşmak için bilinç seviyesinde güçlenmiş olmak durumundadır. Salur Kazan'ın da bilincin hükümdarlığında yenilmez bir kahraman olduğu açıtır. Bu duruma kahraman da öyle aşinadır ki, başarısı ile övünmediğini dile getirir: $O$ anda bile alpım, erim diyerek övünmedim (Ekici 2019:201). Dede Korkut hikâyelerinde ve yazılı kaynaklarda da Kazan'ın "övünmediğini" vurgulayan sözlerine sıklıkla rastlanmaktadır15. Çünkü Korkut Ata'nın "Mukaddime"de ifade ettiği gibi:

14 Yedi sayısı, Schimmel tarafından "Bilgeliğin Sütunları" olarak adlandırılmıștır. Kahraman merkezli anlatılar bağlamında Schimmel: "Yedi gezegenin sayısı, tanrıların, kahramanların ya da kahramanlığı ve yaratıcı bilgeliği sembolize eden bilge adamların mitolojik figürlerinin her yeni kılık değiştirişinde ortaya çıkar." (2011: 144) der.

15 “Salur Kazan'ın Tutsak Olup Oğlu Uruz'un Çıkardığı Boy"da söylediği soylamada da öğünmediği dile getirir:

Tomanın Tekürü karşısında söylediği soylama:

Bin bin erden yağı gördüm-ise öyünüm didüm / Yigirmi bin er yağı gördüm-ise yiylemedüm / Otuz bin er yağı gördüm-ise ona saydum / Kir bin er yağı gördüm-ise kıya bakdum / Elli bin er gördüm-ise el virmedüm / Altmış bin er gördüm -ise aytışmadum / Seksen bin er gördüm-ise segsenmedüm / Toksan bin yağı gördüm-ise tonanmadum / Yüz bin er gördümise yüzüm dönmedüm / Yüzi dönmez kılıcum ele aldum / Muhammedün dini aşkına kılıç urdum / Ağ meydanda yumru başı topça kesdüm / Anda dahı bigem diyü ögünmedüm / Öginen erenlerş hoş görmedüm (Ergin, 2018: 236) 
Tekebbürlik eylenini Tanrı sevmez/ Könlin yüce tutan erde devlet olmaz (Ergin, 2018:73).

Her birey yaşamı boyunca bilinçli alanında- farkında olduğu- çeşitli deneyimler yaşar ve bu deneyimlerden akılda kalıcı dersler çıkarır. 0 deneyimlerin farkında olduğu için tekrar kullanması gerektiğinde, tecrübelerini ustalıkla kullanır. Ancak bireyin mutlaka kendisi ile baş başa kalmayı ve daha derin sularda yüzmeyi de öğrenmesi gerekir. Jung'a göre, yetişkin bir insan kendini bilme durumu üzerine düşünür. Birçok insan kendini bilme ile bilinçli ego kişiliklerini bilmeyi karıştırır. Ego bilinci olan biri, kendini bildiğini kabul eder. Gelin görün ki ego bilse bilse kendi içeriğini bilir. Bilinçdışı ve onun içeriğini bilemez (2018:395). Bilinçdışı ve onun içeriğini bilmek için oldukça zorlayıcı bir yolda, büyük bir çaba harcamak gerekir. Salur Kazan da kendiyle derinleşmeye, "kendini bilme”ye talip olur. Kahraman, yola çıkma kararı verip adım attıktan sonra bilinmezliklerle dolu bir dünyaya giriş yapar.

\section{Bilincin Hükümdarlığından Bilinçdışının Bilinmezliğine}

Salur Kazan, savaş boyunca bilinç seviyesinde istediği başarıları, stratejiler geliştirerek rahatlıkla kazanmıştır. Çünkü imtihanlar iyi bildiği, olgunlaştığı bir alanda gerçekleşmiştir. Benzer zaferler aynı hazları vermeyeceğinden kahraman artık psişesinin en derin, bilinmez ve güvende olmasa da keşfetmek istediği bölümü ile yüzleşmeye hazırdır. Üç yüz yiğidiyle Ak Minkan'a ava giden Salur Kazan, ikindi vakti ava yalnız devam etmek ister. Üç yüz yiğit onun “korunaklı- güvenli alanı"dır. Bu alandan çıkan Salur Kazan, bilinçten bilinçdışına doğru hareket etmiş olur. Salur Kazan'ın ava "yalnız" devam etme isteği ve sonrasında ava ulaşmak için dua etmesi, öz'e (benlik, self) gerçek bir yönelme isteği, kendi psişesini anlama yolu ile tüm hayatı anlamlandırma sürecine girdiğini gösterir. Kahramanın bu süreci tek başına deneyimlemesi gerekir.

Öz'e giden yol, önce her bireyin kendini anlamasından geçer. Jung'a göre ruhsal bütünlük olan öz, bilinçten ve bilincin üzerinde yüzdüğü sonsuz ruh okyanusundan oluşur (2016c: 277) ve öz, yalnızca bir merkez değil; aynı zamanda bilinç ve bilinçdışını çevreleyen bir çemberdir (Fordham, 2004: 79). Ampirik bir kavram olarak öz, insanın bütün psişik fenomen yelpazesine verilen addır (Jung, 2016a: 48 ). Bu kavram daha çok bir yandan kendimize özgü yapımız konusunda bilgilenmemizden, öte yandan yaşamın tümüyle yalnızca insanlarla değil; hayvanlar, bitkiler ve hatta inorganik madde ve evrenin kendisiyle olan yakın ilişkilerimizden oluşmaktadır ki bu bir çeşit "tek başına olma" duygusu verir ( Fordham, 2004: 78 ). Kahramanın yalnız kalma isteği, kaçınılmaz olan bilinçdışı süreçleri keşfetmesinin simgesi olur.

Duymaz, Yazıcıoğlu Selçuknâme'sinde Salur Kazan hakkında yer alan bilgilerin, Dede Korkut Kitabı'ndakilerle örtüştügünü belirtir, bu kaynakta Kazan'ın kendi ile ilgili ifadeleri “(...) övünüm demedim (...) alpım demedim (...) Allah'ın inayetinde Muhammed mucizatında ol yă̆ııı anda batım alpım yeğim dedi, bu dünyada öğünmen, öğünmen. A beylerim öğünürse yer öğünsün (sün)" (Duymaz, 1997: 22-23) şeklindedir. 
Salur Kazan, yiğitleri gidince Ak Minkan tepesine kadar gelir ve karanlık basar. 0, artık tek başına ve karanlıktadır. Karanlık basması ile psişe bilinçdışı alana temas etmiş olur. Bilinçdışı ile özdeşleşmiş önemli kavramlardan biri de "karanlı"tır. Campbell' a göre herhangi biri; herhangi bir toplumda, kendisi için istemli ya da istemsiz olarak, kendi ruhsal labirentinin eğri büğrü geçitlerine inerek, karanlığa doğru yolculuğa girişirse çok geçmeden kendini (...) bir simgesel figürler (...) manzarasının içinde bulur (2017: 96). Salur Kazan'ın da isteği böyle bir manzara ile karşılaşmak, yani psişesinin derinleri ile yüzleşmektir. Bu beklentiler belli bir olgunluktaki psişenin kendini gerçekleştirme ihtiyacından kaynaklanır. Benliğini tanımak ve onun tüm süreçleriyle yüzleşmek kahramanı asıl hükümdarlığa kavuşturacak şeydir.

Salur Kazan, Ak-Minkan tepesinden Kara Dağ'ın ${ }^{16}$ zirvesine kadar çlkar. Ak Minkan bir tepedir ve kahraman orada herhangi bir karşılaşma yaşamamış ve orayı hızlıca geçmiştir. Ak Minkan psişenin bireysel bilinçdışında, bilinçten çok uzak olmayan bölümü olarak görülebilir. Kara Dağ ise adından anlaşılacağı üzere bilinmez karanlığı yani tamamı ile bilinçdışını temsil eder. Kahramanın dağa tırmanışı, benliğe doğru yapılmış bir serüvenin göstergesidir. Kara Dağ, heybetli bir dağdır ve kahramanın gelişkin psişesini temsil eder. Dağın büyüklüğü ve yüksekliği yetişkin kişiliği imgeler (Jung, 2016b: 94).

"Perverdigâr'a el açıp; "Ben beylerimden bir av avlarım diye ayrıldım. Bir av avlayayım, yurduma avsiz gitmeyeyim. Yurduma, orduma sen beni avsiz gönderme" (Ekici 2019: 201).

Jung'a göre, her türlü inancın özünde iki dayanağı vardır. İnanç hem güven ya da bağlılığa numinosum yaşantısına dayanır hem de numinöz yapıda belli bir deneyime, bu deneyimin sağladığı bilinç değişimine inanıp güvenmeye dayanır (2018: 268). Tanrl, mitolojik anlatılarda kahramanı destekleyen yüce bir varlık olarak yer aldığında öz (benlik, kendilik) arketipinin bir tezahürüdür. Dua simgesi, kahramanın bilinçdışını keşfetme ve değişme ihtiyacı içinde olduğunu gösterir. Salur Kazan'ın esirgeyen, besleyen, koruyan Perverdigâr'a dua etmesi, kendi benliğini keşfetme isteğinin, söz büyüsel bir ritüelle gösterilmesi olur. Bu ritüel, psişede bulunan olumlu içsel enerjiyi harekete geçirmenin de bir ifadesidir.

16 Ögel'e göre, “Ak-dağ veya Kara-dağ dağların ak veya kara oluşlarından dolayı söylenmemişti. Dede Korkut'taki "Kara kara dağlar" sözünün içinde daha çok bir duygu bir mana vardır. Gerçi kara renk de bu manada bir rol oynuyordu. Nitekim Orta Asya destanlarında da iri ve büyük bir cüsse "Kara-dağ'ın resmi veya görünüşü" gibi anlatılmaktadır (Ögel, 2010: 550-551). Türk mitolojisinde bir Şamanistin dağlardan ve ırmaklardan bahsettiğini dinlerken bunun gözle görülen dağlardan ve sulardan mı yoksa bu coğrafi isimleri taşıyan insanoğullarından mı bahsettiğini fark etmek güçtür; ruh bizzat dağdır, dağ bizzat ruhtur (İnan, 1986: 51); Korkmaz'ın incelemesinde Uzun Pınar için belirttiği gibi Kara Dağ da "farkındalığın bir aradalığını yaşatan değerli bir mekândır. Bu durum ona "kutsanan bir yer niteliği de kazandırır." (Korkmaz, 1999: 260). 
Dağın zirvesine kadar gitmiş olmak aslında "derin erginlenme alanında bulunmak" demektir. Erginlenme bölgesine girmeye cesaret etmek ve içgüdüsel güce sahip olmanın yeni ve tehlike hissi veren ruh gücünü yaşamaya başlamak, gizemli bilinçdışına giden istikamet konusunda duyarlılık göstermeyi öğrenmek ve sadece içsel duyumlara güvenmektir (Estes, 2016: 104). Böylece kahraman büyük karşılaşmalar, yüzleşmeler ile bilinçdışının kilitli ve karanlık odalarını ziyaret edebilecektir. Salur Kazan dağın zirvesinden ıșıkları görür:

“Kara Dağ’ın eteğinde yedi yerde meșale gibi yanan ışılklar gördü. Yedi yerde koyu koyu tütüp çıkan duman gördü. Kazan bu ışıkları kendi ordusunun meşale ışıkları sandı. Atının üstünde o ışılklara doğru dağın tepesinden aşağıya doğru yola koyuldu" (Ekici, 2019: 201).

Kazan'ın dağın başından bakınca gördüğü ışıklar birer çağrıdır. Libido $^{17}$ kendini güneşle, ışıkla, ateşle, cinsellikle, bereketle ve yetişmeyle kıyaslayarak ifade eder (Jung, 2019: 293). Yaşam enerjisi ve varlık gücü olan libido, kahraman karanlıkta bir hayat belirtisi ararken ışılk şeklinde yer işareti vererek onu kendisine doğru çeker. Fakat bu yeni çağrı- yer gösterme- Kazan'ın daha önce hiç bilmediği bir şekilde geldiği için kahraman, çağrıyı önceki tecrübelerinden hareketle yorumlar, ancak yanılır. Salur Kazan'ın sezgileri, onu umduğundan başka bir duruma sürükler ve aslında onu, yüzleşmesi gereken ile buluşturur.

\section{Arketipik Evre: "Psişenin Karanlık Yönü: Gölge"}

Salur Kazan, "Yedi yer evreni bir ejderhaya rast gelir." (Ekici, 2019: 201) ve onun fiziksel görünüşü ve yaydığı kokuyu önce anlamlandıramaz. Sadece rahatsız ediciliğini hisseder. Yedi sayısı tüm sembolik sayıların en güçlüsü ve etkileyicisidir. Yedi başlı ejderha ve libido göstermektedir ki kahraman, birey olabilmek adına bilinçdışında şekillenip kendisini engelleyen, korkutan ve pasifleştiren tüm yansıtmalarla yüzleşmektedir. Kahraman korktuğu bu yansıtmalarla savaşıp onları alt etmeyi başarırsa bir çeşit yeniden doğum sürecini tamamlayacak ve bilgeleşme yolunda ilerleyecektir.

Jung, insanın bireysel bilinçdışında bulunan diğer yüzünü gölge olarak adlandırır (Fordham, 2004: 62). En bilenen arketiplerden "gölge" belirgin biçimde kişisel bilinçdışında şekillenmektedir. Gölge, bilinçdışı kişiliğin bütünü değildir. 0 , egonun bilinmeyen ya da az bilinen özelliklerini ya da niteliklerinin çoğunlukla kişisel alana ait olan ve bilinçli de olabilen özelliklerini temsil eder. Gölge, bazı yönlerden bireyin kişisel yaşamının dışındaki bir kaynaktan gelen kolektif faktörleri de içerebilir (Jung, 2017: 164). Arketipsel çözümlemeler yapılırken kahramanın savaștığı dev, balina, ejderha vb. semboller araștırmacılar tarafından çoğunlukla gölge olarak yorumlanır. Bu incelemelerin elbette haklılık payı vardır ancak Jung

17 Jung, libidoyu nesnelleștirilmiș bir hayat enerjisi olarak ele alır ve onu "psişik enerji" olarak tanımlar. Bu durumu Jung: "Libidoyu fark gözetmeden enerji ile birlikte kullanıyorum." (2016a: 50) diyerek özetler. 
psikolojisinde, kahramanın savaştı̆̆ sembolik düşmanların kaynağı daha derin komplekslerde gizli olabilir.

"Dönüşüm Sembolleri" isimli eserde, kahramanın dönüşüm süreci şu başlıklar ile aktarılır: Libido, libidonun dönüşümü, kahramanın oluşumu, anne sembolleri ve yeniden doğuş, anneden kurtulma savaşı... Salur Kazan'ın bilinçdışı süreçler içinde, önceki halinden çok daha farklı bir psişe ile bitireceği bu dönüşüm süreci de benzer bir örnek teşkil eder. Ejderha, ilk bakışta gölge arketipi olarak yorumlansa da aslında o, kaynağı kolektif bilinçdışına kadar uzanan evrensel bir arketipi temsil etmektedir: "Korkunç Anne".

Kasımoğlu tarafından "Gölge Arketipinin Bir Örneği Olarak Ejderha" ön başlığı ile yayımlanan makalede ejderha, gölge arketipi olarak ele alınır. Bu yargının dayanağı ise "İnsan ve Sembolleri” isimli eserde Jung'a ait olduğu iddiasıyla yapılan alıntı olmuştur. Ancak "İnsan ve Sembolleri" nin "Kadim mitler ve Modern İnsan" bölümünden yapılan alıntı Jung'a değil, Henderson'a aittir. Henderson, bahsedilen bölümde gölge kavramı ve ejderha ilișkisini aktarmıştır ancak Jung'un neyi vurgulamak istediğini yine aynı bölümde Henderson: "Ne var ki ego, gölge ile Dr. Jung'un 'tahliye savaşı' adını verdiği bir çatışma içindedir. Bu çatışma, ilkel insanın bilinç kazanma mücadelesinde arketipsel kahraman ile ejderhalar ve diğer canavarlar olarak kişileştirilen kötülügün kozmik güçleri arasındaki savaşla ifade edilmektedir. Kahraman figürü bireyin gelişen bilincinde ortaya çlkmakta olan egonun bilinçdışı zihnin ataletini yenmek için kullandığı sembolik araçtır ve bu figür olgun insanı, annenin hakim olduğu dünyadaki bebekliğin mutlu durumuna geri dönmek için duyduğu özlemden kurtarır. (...) Genç, farklılaşmamış ego kişiliği anne tarafından korunmaktadır. (...) Ama ego sonunda bilinçdışından ve hamlıktan kurtulmalıdır ve onun bu 'özgürlük savaşı' çoğu kez kahramanın canavarla savaşıyla sembolize edilir." (Jung, 2017:114) diyerek derinlemesine açıklar. Jung, “Dönüşüm Sembolleri”nde libido gerilemesi kavramının psikolojik temellerini ve anne arketipi ile ilişkisini detaylı biçimde aktarır. Kahramanın bireyleşme yolculuğu; mitoloji, destan ya da halk hikâyelerinde canavarla mücadele simgesiyle bulunduğunda, bu durum, korkunç anneyle mücadelenin göstergesi olabilir.

\section{Arketipik Evre: "Korkunç Anne: Ejderha18”}

Anne arketipi de diğer arketipler gibi sayısız şekilde tezahür edebilir. Anne arketipinin çeşitli simgeleri iyi, olumlu; kötü, olumsuz anlama sahip olabilir. Bu durumu Jung: "ikircikli unsur kader tanrıçalarında da görülmektedir. Kötülük simgeleri; büyücü, ejderha (veya büyük bir balık ya da yılan gibi yutan, bükülen hayvan), mezar, lahit, derin su, ölüm, kâbus ve umacıdır. Bu liste hiç şüphesiz tam değildir sadece anne arketipinin en

18 Birçok mitolojide karşıllğı bulunan ejderhayla ilgili Larousse Semboller Sözlüğü'nde, “Doğu'da olumlu algılanarak kendisine genellikle uyanık bekçi rolü verilir. Batı'da ise kötülüğün somutlaşmıș hali olarak olumsuz bir imaja sahiptir." (2014: 197) ifadesi yer alır. Ejderha simgesi hakkında daha fazla bilgi için bk. (Eberhard, 2000: 104-107). 
önemli nitelikleri sunulmuştur." (2016e: 121-122) diyerek belirtir. Simgesel bir arketip olan ulu annenin olumsuz yönü, korkunç annedir. Korkunç annenin sembollerinden biri "ejderha"dır." Jung: "Ejderha balinanın, korkunç annenin, insanları parçalayıp yiyen ölümcül obur boğazın bir simgesi olduğunu biliyoruz." (2019: 335) ifadesiyle bunu açılar. Hikâyede ejderha ile yüzleme oldukça önemlidir. Bu yüzleşme ile kahraman, korkunç anne arketipi olarak adlandırılan olumsuz bilinçdışı örüntülerin, kendi psisesinde yarattığı tüm sorunları, engellemeleri fark eder. Böylece psişesini farklı şekillerde etkileyen bütün arketipsel unsurları da tanımış olur. Kendi benliğini bilme, kahramanın bireyleşmesi için en önemli koşullardan biridir.

"Korkunç anne" olarak bahsedilen sembol, insan psişesinin libidosunu içine çeker ve bu yok olmak anlamına gelir. Bireyleşme sürecine giden yolu kapatır. Bireyleşmemiş psişe; tek başına, tutarlı bir kişilik ortaya koyamayan bireyi işaret eder ve böyle bir psişede birçok yıkıcı unsurun olması kaçınılmazdır. Bu sebeple kahraman mitlerinde canavarı alt etmek hayati önem taşır. Ego, sonunda bilinçdışıdan (etkilerinden) ve hamlıktan kurtulmalıdır. Bu özgürlük savaşı çoğu kez kahramanın canavarla savaşı ile sembolize edilir (2017: 114). Bir kahramanın "başaracağına" inanmadan zafer kazanması pek mümkün değildir. Bu sebeple kahraman önce kendi psişesini tüm yönleriyle tanımalı ve kendisine güvenmeyi öğrenmelidir.

Salur Kazan, bilinçdışı kaynaklı olan ve psişesinde sorun yaratan unsurla yüzleşir yani bir farkındalık yaşar ancak bu sorunla savaşmak için cesarete ihtiyacı vardır. Libido ister kendi isteği ile ister eylemsizlikten ister kader yüzünden olsun parlak üst dünyayı terk edince tekrar kendi derinliklerine çıktığı asıl kaynağa batar ve bedene ilk girdiği yarık noktasına, göbeğe geri döner. Bu yarık noktasına "anne" denir. Çünkü yaşam dalgası bize ondan ulaşır. Ne zaman insanı ürküten kendi gücünden şüpheye düşüren büyük bir iş başarılması gerekse libido asıl kaynağa geri çekilir ve bu yok olma ile yeni bir yaşam arasında gidip gelen tehlikeli bir andır (Jung, 2016d: 29). Salur Kazan'ın ejderhaya denk geldiği ve ne yapacağını bilemediği anlar, sembolik olarak libidonun asıl kaynağa çekilmesini ve gerilemesini temsil eder. Kahramanın kendine güvenemediği, kuşku duyduğu bu anlar, onu gerçek bir varoluş mücadelesine çağırır.

\section{Arketipik Evre: "Bilge'nin Sesi”}

Canavar kökensel arketip imgelerinden birini oluşturur. Canavarla yüz yüze gelmek gerekir. Çünkü kahraman gibi o da enerji yüklü bir merkezdir. Karşılaşma gerçekleşmediğinde bu eksiklik, insanın doğal gereksiniminin eksikliği ile eşdeğerde olacaktır. Canavarla karşılaşma çeşitli biçimlerde olabilir, önemli olan karşılaşmadır. İnsan kendisiyle karşılaşmadıkça, kendisine yönelmedikçe kendini iyi hissetmez. Ruhsal sıkıntılarla yüz yüze gelmedikçe, kendi yüzeyinde kalır. Kendisiyle çarpıştığı anda darbeden hemen sonra huzur verici yararlı bir izlenim edinir (Jung, 2016c: 256). Kahraman; psişesindeki karanlık, yok edici, çirkin unsurlarla yüzleşmeli, bu unsurları, doğru ve kalıcı bir şekilde aşmayı başarmalıdır. 
Ancak bunu başarmak için de bilge bir sesin desteğine ihtiyaç duyar. Yaşlı bilge ${ }^{19}$ bilinçdışının derinlerinden gelen, kolektif bilinçdışının deneyimlerini barındıran ve kahramanın ihtiyacı durumunda ortaya çıkan 'yüreklendirici' sestir. Bu bilge ses, kahramanın kendi psişesinin derinlerinde, hazır olarak onu beklemektedir. Kahraman, koruyucu figürleri çağırmayı bilmeli ve onlara kulak vermeyi unutmamalıdır.

Salur Kazan, ejderha ile yüzlemek için cesaretlendirilmelidir. Sembolik olarak yaşlı bilge gibi destekleyici figürlerle ilgili Henderson: "Onların özel rolü, kahraman mitinin asıl fonksiyonunun, bireyi (kendi gücünün ya da güçsüzlüğünün farkında olması) hayatta karşısına çıkacak zahmetli görevlere hazırlayacak biçimde ego-bilincin gelişmesi olduğunu gösteriyor." (Jung, 2017:107) diyerek açıklar. Yaşlı bilgenin özgün rolü, kahramanın kendi gücünü ya da güçsüzlüğünü; eksikliklerini ya da meziyetlerini kavramasını sağlamaktır. İște, Lala Kılbaş da bu bilge sesi temsil eder:

“Beyim, karşı yatan Kara Dağ’n gözbebeği sensin, taşkın akan suların durgunu sensin, yılkının aygırı sensin, deve sürüsünün buğuru sensin, koyunların koçu sensin, erenlerin serdarı sensin, yiğitlerin koçağı sensin. Ejderha dedikleri aslı bir yılandır. O yılanın üstüne gitmelisin" (Ekici 2019: 203).

Alplar başı Kazan'a kimliğinin hatırlatılması gerekmektedir. Lala, "Beyim", "yiğitlerin koçağı" ve "sensin" gibi sözleriyle kahramanda sembolik olarak "ben" ve "bilinç" $i$ oluşturarak kendi olumlu psişe unsurlarının hatırlanmasını sağlar. Bu yüreklendirici sözler kahramana kim olduğunu hatırlatır ve savaşacak gücün içinde olduğunu fark ettirir. Salur Kazan da Lala Kılbaş'tan duyduğu yüreklendirici telkinlerle -ki bu telkinler bir çeşit yüksek benlikten gelen direktifler olarak görülebilir- yedi başlı ejderhaya karşı savaşmaya karar verir. Asıl mesele ejderhayı yenebileceğine inanmaktır. Salur Kazan kendisine inanır. Kazan, yitip gitmekten kurtulur, kendi içsel enerjisine güvenir ve farkındalığını yaşar.

Kazan, uyuyan ejderhaya saldırmak mertliğe yakışmaz, hile olur düşüncesiyle uyuyan ejderha uyansın diye bir ok atar. Bu eylem, ejderha ile mücadelenin kahramanca bir başlangıcıdır. Pearson'un “Gerçek savaş̧̧ılar adil bir yarışmayı ya da mücadeleyi destekler. Ancak sahte-savaş̧̧ılar yarışmaya hile karıștırmaktan mutluluk duyarlar." (2003:141) ifadesi Salur Kazan'ın gerçek bir savaşçı olduğunu kanıtlar niteliktedir. "Ok" simgesi ise libidoyu sembolize eder (Jung, 2016d: 28). Jung: "Okun anlamı erkektir. Anne babaların cesur oğullarını mızrak ucu olarak tanımladığı, Doğu’ya özgü bu adetin anlamı budur. 'Keskin oklar yapmak' cesur oğullar yaratmak anlamına gelen bir Arap deyimidir. Çinliler bir oğulun doğduğunu göstermek

${ }^{19}$ Jung'un anlatının arketipi olarak konumlandırdığı "yașlı bilge adam” birçok değișik biçimde karşımıza çıkabilir. Yaşlı bilge adam düşlerde büyücü, doktor, rahip, öğretmen, profesör, dede ya da başka bir yetkili kişi kılığında görünür (Jung, 2018: 139 ). İnsan, gulyabani ya da hayvan görünümündeki ruh arketipi, insanın idrak, anlayıș, iyi tavsiye, karar, plan gibi şeylere ihtiyaç duyduğu ama kendi imkânları ile bunlara ulaşamadığı durumlarda ortaya çlkar (Jung, 2016b: 90). 
için evlerinin önüne ok ve yay asarlardı. (...) ve ok atışı ile ilgili fantezi kişisel özgürlük savaşı ile ilgilidir." (2019: 384,404) diyerek okun, kültürel kökeni ve simgelerini açılar. Ok atmak, içsel enerjinin gücüyle başlatılan bir özgürlük mücadelesinin başlangıcıdır. Salur Kazan, ok atarak korkunç anneden kurtulmak için savaşı başlatır.

Kazan'ın attığı okla başlayan savaşa ejderha da karşılık verir, ateş püskürür. Salur Kazan ve atı, ejderhanın ağzına doğru sürüklenmeye başlar. Kahraman merkezli anlatılarda yardımcı hayvan olarak sıkça kullanılan "at", libidonun bir göstergesidir. At ve binicisi arasındaki bağ önemlidir. Jung tarafından anneyi hedefleyen libidonun kendini at olarak sembolize ettiği dile getirilir (2019: 366). Ejderhanın, kahramanı ve "at sembolü ile gösterilen yaşam enerjisini" yutmak istediği bu bölüm, korkunç annenin açık bir temsilidir.

Bilinçdışında en büyük korkusu ile karşı karşıya kalan Salur Kazan, korkusuna karşı savaşır fakat bu savaş, zorlu bir savaştır ve düşman tarafından yutulmak üzeredir. Kazan, son anda -yenilmek üzereyken- Allah'a dua eder ve yardım ister: Ey Perverdigâr! Sen bana bir kurtuluş yolu göster (Ekici 2019: 203). Yüksek kahramanın büyük görevi, "çokluktaki bu birliğin bilgisine ulaşmak" ve "onu bilinir kılmaktır" (Campbell, 2018: 43). Birlikten kastedilen öz (benlik, kendilik) arketipidir. Tanrı imgesi, öz arketipinin önemli bir sembolüdür. Kahraman içsel gücüne güvenmeyi hiç bırakmazsa büyüsel bir korunmayla ödüllendirilir. İlahi yardımla psișenin korucuyu bir sembolü olan kaya ortaya çlkar. Salur Kazan, kayanın kuytusuna geçer. Bu göksel yardım kıymetli bir haberci görevi de görür, Kazan, kendiyle mücadele ederken psişesinin tüm unsurlarından gelen olumlu yönleri kullanmayı başarmıştır.

\section{Arketipik Evre: "Bütünlük ve Denge"}

Ejderhanın heybetinden Kazan'ın "bir gözü kan çanağına döner"20. "Göz", görünür olanın yani bilincin ışığıdır. Fark etmek, takip etmek ve yol bulabilmek için göze ihtiyaç vardır. Gözün bulanması, kan dolması hem bilinçdışı süreçlerdeki işlevsizliğini hem de korkudan-kaygıdan ötürü bilinçdışındaki psişenin yönünü bulamayışını sembolize eder.

Kazan, yalnızca bilinçli yaşamı içinde ne kadar sınırlı bir algı ve duyum dünyası olduğunu idrak etmiștir. Tam hiddetlenip bu yetersiz yönünü yok etmek istemiştir ki "Eğer ben kendi gözümü oyarsam, Kazan ejderhayı görünce korkusundan başka bahane bulmayıp, gözlerini çıkarmış derler"

\footnotetext{
20 Salur Kazan, “Salur Kazan'ın Tutsak olup Uruz'un Çıkarttığı Boy”da yer alan soylamasında da sol gözünün yaşarması üzerine gözüyle söyleşmesi şöyledir:

Yedi başlı ejderhaya yetüp vardum / Heybetinden sol gözüm yaşardı / Hey gözüm namet gözüm muhannes gözüm / Bir yılandan ne var ki korhdun, dedüm. (Ergin, 2018: 237).
} 
(Ekici 2019: 203) diye düşünüp vazgeçer. Anlatılarda persona ${ }^{21}$, kahramanın kendi benliğinden gelen dürtüler yerine, toplumun beklentilerine uygun olan davranışa yönelmesi durumunda ortaya çıkar. Persona yalnızca arkasına gizlenilen bir maske değildir; daha çok dünyevi kişiliğe gölgesini düşüren bir mevcudiyettir. Bu anlamda persona ya da maske mevkiinin, erdemin, karakterin ve otoritenin bir işaretidir (Estes, 2016: 112-113). Salur Kazan da ondan beklenilene kulak verir ve böylece kahramanın bilinçdışı süreçlerden bireyleşmesini tamamlayarak çıkacağı ve bilinç seviyesindeki yaşantısının da beklentileri noktasında farkındalığını koruyacağı yani dengeli bir psişe yapısına kavuşacağı anlaşılır.

Psişenin tutarlı birliği, kahramanın büyük gücü olacaktır. Jung’a göre, "bilinç kendi davasını savunup kendini korumalıdır. Bilinçdışının kaotik yaşamı da kendi yoluna gitmeli ve dayanabildiğimiz kadar ilerlemelidir. Bu aynı anda hem "açık çatışma" hem de "açık işbirliği" demektir. Sürecin simgeciliği özel bir bölümdür. Bu sürecin bilinç ile bilinçdışı arasındaki karşılaşmanın son evresini hem pratikte hem de kuramda anlama bakımından büyük önemi vardır" (2018: 252). Bilinç seviyesinde algılanan yaşam için bilinçdışı görmezden gelinemez ve bilinçdışı süreçler sonucunda da bilinç seviyesindeki yaşam ihmal edilemez. Çünkü kahramanın bireyleşmeyi başardığının ispatı, denge halinde yürüttüğü bilinç ve bilinçdışı süreçlerin uyumlu bütünlügüdür.

Kahraman Salur Kazan, önce çok korksa da içindeki bilgeyi dinleyerek ejderhayla savaşır ve onu öldürmeyi başarır. Kazan'ın ejderhayı öldürdükten sonra Lala'ya söylediği sözler de onun kendini bilme yolunda ilerlediğinin bir göstergesidir: "Ejderhayı ben öldürmedim. Senin bana verdiğin cesaret ve güç öldürdü." (Ekici, 2019: 20). Kahraman en zor anında, harekete geçirdiği içsel bilge ses sesin direktifleriyle, psişesini olumsuz etkileyen, bireyleşmesini engelleyen tüm sebeplerden kurtulur. Kahraman, libidosunun tüm gücü ile varoluş mücadelesi vermiştir. Bireyleșme süreci için savaşmış ve psişesinin engelleyici unsurlarından böylece arınmıştır. Her zaferin bir nişanesi olur. Kazan'ın zaferinin nişanesi de ejderhanın derisidir:

"Kazan, ejderhanın derisinden, korkusuz bedenine giysi diktirdi: (...) kurt tokalı Konur At'ın eyerine örtü diktirdi; gölgeliğin yelkenlerini ejderha derisinden yaptırdı. Ejderhanın yedi başını hiç israf etmeden yüzdürüp ejderhanın iki kafa derisini Kazan kendi başına giydi" (Ekici, 2019: 204).

21 Jung, antik dönemde oyuncuların taktıkları maskeden hareketle persona arketipini adlandırmıștır. İnsanoğlunun uygarlaşma süreci, insan ve toplum arasında onun nasıl görünmesi konusunda ve birçok insanın arasına gizlenerek yaşadığı maskenin oluşması konusunda bir uzlaşma getirir (Fordham, 2004: 60). Jung' a göre insanlar, bilinçli maksatlarıyla tutarlı olduğunu bildiği bir maske takar. Bu maske toplumun da taleplerini karşllar ve görüșlerine uygundur. Önce bir sonra bașka bir güdü ile büyük avantaj sağlar (Jung 2016a: 56). Bir dereceye kadar insanların kendilerine en uygun rolleri seçtikleri doğrudur. Persona bu derece bireyseldir; ancak hiçbir zaman erkek ya da kadının tümü sayılmaz. İnsan doğası tutarlı değildir ama bir rolü oynarken tutarlı görünmek zorundadır. Bu yüzden de kaçınılmaz olarak olduğundan başka biçimde görünmektedir (Fordham, 2004: 61). 
Düşmanın kalbi yendiği ya da kafa derisi yüzüldüğü takdirde cesaretinin ve gücünün ele geçirilmesi gibi ( Jung, 2019: 242) büyüsel bir anlam vardır. Salur Kazan psişesindeki korkunç annenin ölümü ile cesaretini ve gücünü kazanır. Ayrıca İnuitler arasında hem kürkün hem de tüylü derinin çok uzaklarda olup bitenleri görme yeteneğine sahip olduğuna inanılır ve bir şamanın bir sürü kürk ve tüylü deri giymesinin nedeni de budur. Böylece şaman gizleri daha iyi görebileceği yüzlerce göze sahip olur (Estes, 2016: 298). Dilediğinden çok daha haşmetli bir av avlayarak yurduna mutlak zaferle dönen Salur Kazan, yedi başlı ejderha derisini üstüne alarak da tüm cesareti ve gücüyle "bilgeliğin tacı"nı takmış olur.

Salur Kazan anlatının sonunda geri dönüp gelir ve bir çadır kurdurur: "Ejderha derisinden yapılmış gölgeliği dikti. Bayındır Padişah gölgeliğin altında bağdaş kurup oturdu" (Ekici, 2019: 204). Çadır, "birleştirici simge" unsurunun açık bir örneği olarak dikkat çekmektedir. Bilgelik tacını takan Salur Kazan toplumuyla da bir çatı altında bütünleşmiş̦tir. Birleștirici simge altında, psişenin tüm unsurlarının dengeli birlikteliği, bireyleşmeyi başarmış kahramanın zaferidir.

\section{Sonuç}

Hünerli ve erdemli Salur Kazan'ı daha derinden tanıma firsatı veren 13. Boy'la yeni bir kapı aralanmıştır. Analitik psikolojisinin sembolik çözümlemeleriyle bütün boylarda "alpım", "erim" diyerek övünmeyen Salur Kazan'ın bu "meziyetlerini" neden dile getirmediği bilinçdışına yapmış olduğu yolculuğun derinliğinden de anlaşılmaktadır. Kibirden arınmış Kazan Bey, kendini tanıma, kendi özelliklerinin bilincine varma üzerine bir yolculuğa çıkarak hem bilinci hem de bilinçdışını kucaklayan çemberin içinde, arketipsel unsurlarla karşılaşmış, karanlık dehlizlerde korkunç anneyle yüzleșerek yeniden doğmuştur. Psișesinin tüm unsurlarıyla bütünlük kurarak serüvenini tamamlayan Salur Kazan, dengeye ulaşarak toplumla birleşmiş, inanç ve güven objesine dönüşmüștür. Böylece alplar alpı önemli bir serüveni tamamlayan Salur Kazan, bilgeliğin tacını takarak "bilge alp" olarak anılmayı hak etmiştir.

\section{KAYNAKÇA}

Abdullah, K. (2012). Mitten yazıya veya gizli Dede Korkut. (akt. Ali Duymaz) İstanbul: Ötüken Neşriyat.

Azmun, Y. (2019). Dede Korkut'un üçüncü elyazması (Soylamalar ve iki yeni boy ile Türkmen Sahra Nüshası). İstanbul: Kutlu.

Bars, M. E. (2010). Salur Kazan'ın Evi Yağmalandığı Boy'da Salur Kazan ve Çoban. The Journal of Academic Social Sciences Studies, 3 (2), 55-63.

Campbell, J. (2017). Kahramanın sonsuz yolculuğu. (Çev.: Sabri Gürses), İstanbul: İthaki.

Duymaz, A. (1996). Kıpçak Sahası Türk destanlarında bir Oğuz alpı: Salur Kazan. Milli Folklor, S. 31-32, 49-59.

Duymaz, A. (1997) Bir destan kahramanı Salur Kazan. İstanbul: Ötüken. 
Duymaz, A, (1999). Dede Korkut Kitabı'nda alplığa geçiş ve topluma katılma törenleri üzerine bir değerlendirme. Uluslararası Dede Korkut Bilgi Şöleni, 109-122; Ankara: Atatürk Kültür Merkezi Başkanlığı.

Eberhard, W, (2000) Çin simgeleri sözlüğü. (Haz.: Sabri Gürses, Zeliha Güler), İstanbul: Kabalcı Yayınevi.

Ekici, M. (2019). Dede Korkut Kitabı Türkistan/ Türkmen Sahra Nüshası Soylamalar ve 13. Boy Salur Kazan'ın Yedi Başlı Ejderhayı Öldürmesi. İstanbul: Ötüken.

Ergin, M. (2018). Dede Korkut Kitabı I-II. Ankara: Türk Dil Kurumu.

Estés, C. P. (2016). Kurtlarla koşan kadınlar. (Çev.: Hakan Atalay), İstanbul: Ayrıntı.

Fordham, F. (2004). Jung psikolojisinin ana hatları. (Çev.: Aslan Yalçıner), İstanbul: Say.

Gardin, N. - Olorenshaw, R. - Gardin, J. - Klein, O. (2014). Larousse semboller sözlüğü. (Çev.: Beyza Akşit), İstanbul: Bilge Kültür Sanat.

Gökyay, O. Ş. (2000). Dedem Korkudun Kitabı. İstanbul: Milli Eğitim Bakanlığı.

İnan, A. (1986). Tarihte ve bugün Şamanizm - Materyaller ve araştırmalar. Ankara: Türk Tarih Kurumu.

Jacobi, J. (2002). C. G. Jung psikolojisi. (Çev.: Mehmet Arap), İstanbul: İlhan.

Jung, C. G. (2016a). Analitik psikoloji sözlüğü. (Çev.: Nur Nirven), İstanbul: Pinhan.

Jung, C. G. (2016b). Dört arketip. (Çev.: Mert Hüseyin Ergül), İstanbul: Olympia.

Jung, C. G. (2016c). İnsan ruhuna yöneliş. (Çev.: Engin Büyükinal), İstanbul: Say.

Jung, C. G. (2016d). Maskülen erilliğin farklı yüzleri. (Çev.: Didem Gamze Erdinç), İstanbul: Pinhan.

Jung, C. G. (2016e). Feminen dişilliğin farklı yüzleri. (Çev.: Tuğrul Veli Soylu), İstanbul: Pinhan.

Jung, C. G. (2017). Insan ve sembolleri. (Çev.: Hatice Mukaddes İlgün), İstanbul: Kabalcl.

Jung, C. G. (2018). Seçme yazılar. (Çev.: Levent Özşar), İstanbul: Alfa.

Jung, C. G. (2019). Dönüşüm sembolleri. (Çev.: Firuzan Gürbüz Gerhold), İstanbul: Alfa.

Kaplan, M. (1976). Türk destanlarında alp tipi. Türk Edebiyatı Araştırmaları. İstanbul: Dergâh.

Kasımoğlu, S. (2019). Gölge arketipinin bir örneği olarak ejderha: Salur Kazan'ın Yedi Başlı Ejderhayı Öldürmesi'nin Arketipsel Tahlili. Turnalar, S. 76, 33-38.

Korkmaz, R. (1999). Fenomenolojik açıdan Tepegöz yorumu. Uluslararası Dede Korkut Bilgi Şöleni, 259-269, Ankara: Atatürk Kültür Merkezi Başkanlığı.

Ögel, B. (2014). Türk mitolojisi. C. II, Ankara: Türk Tarih Kurumu.

Kargı Ölmez, Z. (1996). Ebulgazi Bahadır Han. Şecere-i Terakime (Türkmenlerin Soykütüğ̈̈). Ankara: Simurg.

Pearson, C. S. (2003). İçimizdeki kahraman. (Çev.: Semra Ayanbaşı), İstanbul: Akaşa. Segal, R. (2004). Mit. (Çev.: Nursu Örge), Ankara: Dost Kitabevi.

Schimmel, A. (2011). Sayıların gizemi. (Çev.: Mustafa Küpüşoğlu), İstanbul: Kabalcı. Stevens, A. (2014). Jung. (Çev.: Nursu Örge), Ankara: Dost. 